\title{
GTF2F1 wt Allele
}

National Cancer Institute

\section{Source}

National Cancer Institute. GTF2F1 wt Allele. NCI Thesaurus. Code C52618.

Human GT F2F1 wild-type allele is located in the vicinity of 19p13.3 and is approximately $108 \mathrm{~kb}$ in leng th. This allele, which encodes transcription initiation factor IIF subunit alpha protein, plays a role in the mediation of transcriptional elongation. 